Article

\title{
Hypovitaminosis D Influences the Clinical Presentation of Immune Thrombocytopenia in Children with Newly Diagnosed Disease
}

\author{
Davor Petrovic ${ }^{1, *(D)}$, Benjamin Benzon ${ }^{2}$, Marijan Batinic ${ }^{1}$, Srđana Culic ${ }^{1}$, Jelena Roganovic ${ }^{3}$ \\ and Josko Markic 1,4 (D) \\ 1 Department of Pediatrics, University Hospital of Split, Spinciceva 1, 21000 Split, Croatia; \\ marijan.batinic23@hotmail.com (M.B.); srdjana.culic.sc@gmail.com (S.C.); jmarkic@mefst.hr (J.M.) \\ 2 Department of Neuroscience, University of Split School of Medicine; Soltanska 2, 21000 Split, Croatia; \\ benzon.benjamin@gmail.com \\ 3 Department of Pediatrics, University Hospital of Rijeka, Braće Branchetta 20/1, 51000 Rijeka, Croatia; \\ roganovic.kbcri@gmail.com \\ 4 Department of Pediatrics, University of Split School of Medicine, Soltanska 2, 21000 Split, Croatia \\ * Correspondence: dpetrovic@kbsplit.hr
}

Received: 6 October 2019; Accepted: 1 November 2019; Published: 3 November 2019

\begin{abstract}
Immune thrombocytopenia (ITP) is an acquired autoimmune disorder characterized by isolated thrombocytopenia defined as platelet count in peripheral blood $<100 \times 10^{9} / \mathrm{L}$. Hypovitaminosis $\mathrm{D}$ is very common in children with autoimmune diseases. To analyze whether hypovitaminosis $\mathrm{D}$ is associated with the clinical presentation of ITP in children, medical records of 45 pediatric patients with newly diagnosed immune thrombocytopenia in the coastal region of Croatia were evaluated. The severity of bleeding was assessed using two bleeding scores. Children with lower 25-hydroxyvitamin $\mathrm{D}(25(\mathrm{OH}) \mathrm{D})$ values had higher values of the skin-mucosa-organ-gradation (SMOG) bleeding score and respectively more severe bleeding on diagnosis of ITP. With further analysis of the main domains of that score, we found that patients with a lower $25(\mathrm{OH}) \mathrm{D}$ value had more severe bleeding in the skin and organs. When $25(\mathrm{OH}) \mathrm{D}$ and ITP Bleeding Scale (IBLS) score were analyzed, a negative correlation was found, but it was not significant. Our findings suggest that hypovitaminosis D influences the severity of the clinical presentation of ITP in children on initial diagnosis of the disease. Therefore, therapy with $25(\mathrm{OH}) \mathrm{D}$ could be a new potential option for treatment of ITP. To investigate the connection between $25(\mathrm{OH}) \mathrm{D}$ and the incidence and severity of ITP, further studies, especially randomized controlled studies, are needed.
\end{abstract}

Keywords: 25(OH)D; vitamin D deficiency; immune thrombocytopenia

\section{Introduction}

Immune thrombocytopenia (ITP) is an acquired autoimmune disorder characterized by isolated thrombocytopenia defined as platelet count in peripheral blood $<100 \times 10^{9} / \mathrm{L}$ [1]. In most patients, the number of platelets in peripheral blood is less than $30 \times 10^{9} / \mathrm{L}$ - of which, $80 \%$ have a platelet count $<20 \times 10^{9} / \mathrm{L}$, and $44 \%$ have a count $<10 \times 10^{9} / \mathrm{L}[2,3]$.

The incidence of ITP in children is approximately $4-8$ per 100,000 person-years $[1,4,5]$. It is usually a benign disease and spontaneously subsides within 3 months. ITP lasting for 3-12 months is called persistent thrombocytopenia, while thrombocytopenia lasting $>12$ months is considered as a chronic form of ITP (occurring approximately in $20 \%$ of cases) [6-8]. 
It is assumed that the key pathophysiological mechanism important for ITP development is a loss of immune self-tolerance followed by the development of autoantibodies against platelet membrane antigen, mostly glycoprotein complexes IIb/IIIa [1]. In most cases, ITP develops after a viral infection [4].

ITP manifests with sudden purpura and hematoma in previously healthy children. Skin changes such as petechiae and purpura can be found in $60 \%$ of children, whereas mucous membrane bleeding (epistaxis, buccal bleeding, hematuria, menorrhagia, and gastrointestinal bleeding) can be found in $40 \%$ of children $[9,10]$. Approximately $3 \%$ of children develop severe bleeding events [11]. The most severe complication of ITP is intracranial bleeding, with an incidence of $0.1 \%-0.8 \%$, which is more often found in children with a platelet count under $10 \times 10^{9} / \mathrm{L}$ [1,11-13].

Before starting medical treatment, the intensity of the disease should be determined. Clinical examination is more important than the number of platelets because children with severe thrombocytopenia $\left(<10 \times 10^{9} / \mathrm{L}\right)$ may have mild symptoms [14].

Various bleeding scores are available for the assessment of bleeding severity in ITP patients. They are used to standardize the treatment choice as well as follow up on the administered therapy [8,15-18]. In our study, we have chosen two recent scores, an ITP Bleeding Scale (IBLS) assessment system [17], and skin-mucosa-organ-gradation (SMOG) of bleeding score [18], which will be detailed in the Materials and Methods section.

The initial approach to ITP patient treatment is often an individual one. Generally, a "watch and wait" approach is used and later followed up with or without pharmacological treatment [19-21]. Approximately $50 \%-70 \%$ of children recover spontaneously within 3 months. Although the "watch and wait" approach is effective in the majority of children [2,22], better quality of life and fewer relapses were found in those with pharmacological intervention [23-26]. Commonly used medications include intravenous immunoglobulin (IVIG), intravenous anti-D immunoglobulin (anti-D) or glucocorticoids and, recently, agonists of thrombopoetin receptors (TPO-R) [1,27].

Vitamin $\mathrm{D}(\mathrm{VD})$ is a pro-hormone produced from 7-dehydrocholesterol when exposed to ultraviolet light radiation. It is biologically inert and to be activated, it has to be metabolized in the liver into 25-hydroxyvitamin D (25(OH)D), and then in the kidneys into $1 \alpha$, 25-hydroxyvitamin D3. The active form of VD affects the absorbance of calcium and phosphate in the intestine, calcium mobilization in bones and reabsorbance of calcium in the kidneys [28]. VD function is not only limited to its role in the homeostasis of calcium, its action is additionally mediated via the VD nuclear receptor (VDR), which belongs to the superfamily of steroid hormone receptors and thyroid gland hormones $[29,30]$.

In recent years, the importance of VD has been examined in immune and inflammatory response. VD regulates hormone secretion and cell proliferation and differentiation [31,32]. VD is also the regulator of the hematopoietic system -it modulates the activation and proliferation of lymphocytes, induces differentiation of monocytes in the promyelocytes and inhibits the secretion of several cytokines in T-cells [33,34].

Various studies have demonstrated the ability of VD to suppress the synthesis of interferon-gamma (IFN $\gamma$ ) and interleukin-2 (IL-2) in peripheral blood lymphocytes (PBL) and T-cell lines [35,36], confirming its immune-modulating function. Correlation between hypovitaminosis D and a higher incidence of infections and autoimmune diseases was reported as well [37-42]. It has been demonstrated that supplementation with VD is beneficial for Th1-mediated autoimmune response [43]. Likewise, VD insufficiency turns immune response towards a loss of tolerance [42,44].

Fatizzo et al. found low 25(OH)D values in adults with ITP [45], but further studies on this matter are warranted. To the best of our knowledge, there are no studies about the influence of hypovitaminosis D on ITP clinical presentation in children, especially studies that used different bleeding assessment tools. With this study, we analyze whether hypovitaminosis D is associated with a lower platelet count and severity of the clinical presentation of ITP in children.

Our hypothesis is that children with ITP who have lower levels of $25(\mathrm{OH}) \mathrm{D}$ at the time of ITP diagnosis will have more pronounced bleeding (indicated through higher values of bleeding SMOG and IBLS scores) in addition to a lower platelet count in peripheral blood. 


\section{Materials and Methods}

\subsection{Study Design}

The study was an observational cross-sectional study.

Our primary outcomes were the correlation between $25(\mathrm{OH}) \mathrm{D}$ value and platelet count and the correlation between $25(\mathrm{OH}) \mathrm{D}$ value and clinical presentation of ITP determined using SMOG and IBLS bleeding scores at the time of ITP diagnosis.

Our secondary outcomes were the correlation between the patient gender and age with the severity of ITP. We also evaluated the correlation of the same variables with $25(\mathrm{OH}) \mathrm{D}$ values.

The Ethics Committee of the University Hospital of Split and Rijeka has approved this study. Written informed consent has been signed by all the participants' parents.

STrengthening the Reporting of OBservational studies in Epidemiology (STROBE) guidelines were used for the creation of this paper [46].

\subsection{Study Population}

Participants were children who were hospitalized in Departments of Pediatrics (Division for pediatric hematooncology) due to newly diagnosed ITP at the University Hospital of Split in the period from 1 January 2013 until 31 December 2018 and at the University Hospital of Rijeka in the period from 1 January 2017 until 31 December 2018. We included eligible participants consecutively. Inclusion criteria were age between 0 and 18, ITP diagnosed by clinical examination and laboratory workup (platelet count in peripheral blood $<100 \mathrm{G} / \mathrm{L}$ ). Patients whose parents did not consent to participation in the research and patients with the missing data were excluded. We also excluded patients who received blood products in the period of one month before the diagnosis of ITP as well as patients with secondary thrombocytopenia as part of another confirmed acute and/or chronic disease which was not ITP.

\subsection{Variables}

For every participant, after being hospitalized for the first time due to ITP, the following parameters were evaluated: $25(\mathrm{OH}) \mathrm{D}$ value, platelet count in peripheral blood, SMOG score, and IBLS score. We also collected data on patients' age, gender, and place of residence on the day of ITP diagnosis. Medical records were used to collect mentioned data.

Patients' peripheral venous blood was sampled in a standard BD Vacutainer ${ }^{\circledR}$ SSTII Advance (BD, Plymouth, UK) tubes and sent to Department of medical laboratory diagnostics of University Hospital of Split and Rijeka for analysis. The level of serum 25(OH)D was analyzed by using commercially available Elecsys Vitamin D total assay with a Cobase601 analyzer (Roche Diagnostics International Ltd., Rotkreuz, Switzerland). This essay measures 25(OH)D values using a competitive electrochemiluminescence binding technique. The detection range of the test is $7.5-175 \mathrm{nmol} / \mathrm{L}$ $25(\mathrm{OH}) \mathrm{D}$, and the sensitivity of the assay is $5 \mathrm{nmol} 25(\mathrm{OH}) \mathrm{D} / \mathrm{L}$. The intraclass coefficient of variations $(\mathrm{CV})$ was $5.3 \%$ at $39 \mathrm{nmol} 25(\mathrm{OH}) \mathrm{D} / \mathrm{L}, 5.6 \%$ at $67 \mathrm{nmol} 25(\mathrm{OH}) \mathrm{D} / \mathrm{L}, 6.7 \%$ at $165 \mathrm{nmol} 25(\mathrm{OH}) \mathrm{D} / \mathrm{L}, 2.2 \%$ at $174 \mathrm{nmol} 25(\mathrm{OH}) \mathrm{D} / \mathrm{L}, 3.9 \%$ at $71.8 \mathrm{nmol} 25(\mathrm{OH}) \mathrm{D} / \mathrm{L}$, and $5.2 \%$ at $39.5 \mathrm{nmol} 25(\mathrm{OH}) \mathrm{D} / \mathrm{L}$. In addition, the Limit of Blank, Limit of Detection, and Limit of Quantification were 5.0, 7.5 and $12.5 \mathrm{nmol} / \mathrm{L}$, respectively. All the samples were analyzed in duplicate. The method was standardized based on international standards. Sufficient and recommended $25(\mathrm{OH}) \mathrm{D}$ values in children are $>75 \mathrm{nmol} / \mathrm{L}$, and everything below that level is regarded as hypovitaminosis $\mathrm{D}[47,48]$. If $25(\mathrm{OH}) \mathrm{D}$ value was between 50 and $75 \mathrm{nmol} / \mathrm{L}$, it was considered as insufficiency, while 25(OH)D values under $50 \mathrm{nmol} / \mathrm{L}$ were considered VD deficiency [48].

At the time of diagnosis, patients were examined to assess the severity of clinical presentation by calculating the bleeding score according to the recommendations of the International Working Group (IWG) for ITP in the SMOG system [18] and also the IBLS system that was created by Page and Psaila [17]. Each bleeding score was calculated by two independent pediatric hematogists. 
In the case of a difference between the scores, the scores were checked by a head of division for pediatric hematooncology.

The SMOG system is a system for the categorization of bleeding level in ITP. The score of bleeding according to SMOG system is calculated as follows: bleedings are grouped into 3 main domains: $\mathrm{S}$ (skin), $\mathrm{M}$ (mucous membranes), $\mathrm{O}$ (organs) with gradation of the intensity of bleeding $(\mathrm{G})$. Ratings are given at the time of examination from 0 up to 3 or 4 (with a score of 5 for fatal bleeding). For mucous membranes (e.g., epistaxis), the rating scale is from 0 to 4 ; for the organ domain (except for intracranial and intraocular bleeding), the rating scale is $0,2,3$ and 4 . For other places of bleeding (in skin and mucous membranes), ratings of 0 to 3 are assigned. If the patient reports bleeding but there is no evidence for that during examination or in medical documentation, a score of 1 is given. Within each domain, the same rating is given for bleedings with similar clinical influence. For the exact evaluation of bleeding in each domain, a table is used for the assessment, which can be found on the official website of IWG. For example, if the rating for a skin domain is 2 , for mucous membranes 1 and organs 1 , then the final index is S2M1O1. It can also be used to sum up mentioned ratings according to domains to obtain a final numerical rating. A higher SMOG score represents more severe bleeding [18]. In this study, we used SMOG final numerical ratings and individual ratings in skin, mucosa and organs for statistical analysis.

The IBLS system assigns ratings from 0-2 for 9 selected sites of bleeding (skin, mouth, epistaxis, gastrointestinal, urinary, gynaecological, pulmonary, intracranial, and subconjuctival) [17].

\subsection{Statistics}

\subsubsection{Calculation of the Minimal Sample Size}

To prove our first hypothesis, we used unpublished and published data from a pilot study of Culic et al. [49] for calculating our minimal sample size. In that pilot study, 21 participants were included. For the modeling of correlation between the 25(OH)D and SMOG score, we used a linear model and Deming's methodology [50]. Based on the data from the pilot study, even with 21 participants, we achieved statistical relevance for the slope $(-0.06,95 \%$ confidence interval (CI) $(-0.22$ to -0.05$))$. However, we need to increase the number of participants to a minimum of 30 to keep the power of the study at $80 \%$ and the probability of type 1 error at $5 \%$.

Deming's methodology is a method of linear regression type 2 (Method II), using a Reduced Major Axis (RMA) variant [50]. In our pilot study [49], we obtained results that the $95 \%$ CI coefficient slope does not include 0 , according to which we already have enough patients not to commit a type 2 error; so, our only concern is to keep the formal level of type 1 error at $5 \%$. As there is no software to calculate the size of sample for the RMA variant of regression, we used network software to calculate the sample size (Soper DS, a priori sample size calculator for multiple regression, 2017) and concluded that the sample we can muster (30 patients) guarantees a margin of type 1 error of $5 \%$ and power of $80 \%$ to discover medium to large (Cohen $\left.f^{2}=0.29\right)$ differences between the null and alternative hypotheses.

\subsubsection{Statistical Tests Used in the Study}

Depending on distribution, descriptive data were shown as a mean value with standard deviation. The correlation between SMOG score with $25(\mathrm{OH}) \mathrm{D}$ values was examined by Spearman's correlation coefficient and linear regression. Furthermore, relationships between the components of SMOG score and $25(\mathrm{OH}) \mathrm{D}$ values were tested by a test for linear trend or $t$ test. Statistical analysis was performed in GraphPad Software (La Jolla, CA, USA), and the level of significance was set to 0.05 . For each effect size, a 95\% CI was given.

\section{Results}

During the study period, a total of 67 newly diagnosed patients with immune thrombocytopenia-57 from University Hospital of Split and 10 from the University Hospital of 
Rijeka-were eligible for inclusion in the study. Of these, 22 subjects (32\%) were excluded due to: diagnosis of chronic thrombocytopenia (11), secondary thrombocytopenia as part of another confirmed acute and/or chronic disease (3), and missing data (8). In total, 45 patients (67\%) were included in the study.

There were 22 males (48\%) and 23 females (52\%). VD insufficiency was detected in 20 patients $(44 \%)$, VD deficiency in 10 patients $(22 \%)$, and 15 patients $(33 \%)$ had a sufficient value of $25(\mathrm{OH}) \mathrm{D}$ at ITP diagnosis.

Distribution data of the age at presentation, platelet count, 25(OH)D value, SMOG and IBLS score can be found in Table 1.

Table 1. Distribution of age, $25(\mathrm{OH}) \mathrm{D}$, platelet count, IBLS and SMOG score at presentation of ITP $(n=45)$.

\begin{tabular}{lccc}
\hline \multicolumn{1}{c}{ Variable } & $\begin{array}{c}\text { All Patients } \\
(\boldsymbol{n}=\mathbf{4 5 )}\end{array}$ & $\begin{array}{c}\text { Sufficient } 25(\mathbf{O H}) \mathbf{D} \text { Value } \\
(\boldsymbol{n}=\mathbf{1 5})\end{array}$ & $\begin{array}{c}\text { Hypovitaminosis D } \\
(\boldsymbol{n}=\mathbf{3 0})\end{array}$ \\
\hline & \multicolumn{3}{c}{ Mean \pm SD } \\
\hline Age at presentation, year & $5.6 \pm 4.8$ & $3 \pm 3.3$ & $6.9 \pm 5$ \\
25(OH)D, nmol/1 & $65 \pm 24$ & $93 \pm 15$ & $52 \pm 15$ \\
Platelets, G/L & $9.8 \pm 10$ & $6.9 \pm 7.7$ & $11 \pm 11$ \\
IBLS $^{1}$ & $4.7 \pm 1.9$ & $4.2 \pm 2.1$ & $4.9 \pm 1.8$ \\
SMOG $^{2}$ & $4.3 \pm 1.5$ & $3.6 \pm 1.4$ & $4.6 \pm 1.5$ \\
\hline
\end{tabular}

${ }^{1}$ IBLS-Immune thrombocytopenia bleeding scale [17]; ${ }^{2}$ SMOG-skin-mucosa-organ-gradation of bleeding in immune thrombocytopenia [18]; SD—standard deviation.

In our study, $28 \%$ of patients (13) had more severe mucosal or organ bleeding (in SMOG M or O value $>2$ ) on the day of ITP diagnosis. Of those 13 patients, six had mucosal bleeding, seven had organ bleeding and four had both mucosal and organ bleeding. There were no cases of intracranial bleeding in our study.

\subsection{Correlation between $25(\mathrm{OH}) \mathrm{D}$ and SMOG Score}

We found a significant linear relationship between 25(OH)D value and SMOG $(p=0.006)$, which shows that patients with a lower 25(OH)D value have a higher SMOG score. To further confirm that hypovitaminosis D inversely correlates with the SMOG score, we also compared $25(\mathrm{OH}) \mathrm{D}$ values with every main domain of SMOG score. In patients with a different severity of bleeding in the skin (S parameter in SMOG score), we found that patients with a lower 25(OH)D value had more severe bleeding in the skin with a difference between means (S2 and S3 group in SMOG score) of $26 \pm 7 \mathrm{nmol} / \mathrm{L}(p=0.001)$. There was no significant connection between the severity of bleeding in mucosa and $25(\mathrm{OH}) \mathrm{D}$ values. We found a significant negative trend $(p=0.03)$ that showed us there is more severe organ bleeding in patients with lower $25(\mathrm{OH}) \mathrm{D}$ values. These results are all shown in detail in Figure 1.

Using the Spearman nonparametric correlation, we also found a statistically significant correlation between the $25(\mathrm{OH}) \mathrm{D}$ value and the SMOG score $(p=0.01$, Spearman $r=0.36)$.

\subsection{Correlation between $25(\mathrm{OH}) D$ and IBLS Score}

When we analyzed the VD value and IBLS bleeding score, we found a negative correlation between the two variables but it was not significant $(p=0.13)$ (Figure 2). With Spearman nonparametric correlation, we obtained similar results (Spearman $r=-0.18, p=0.22$ ). 
(a)

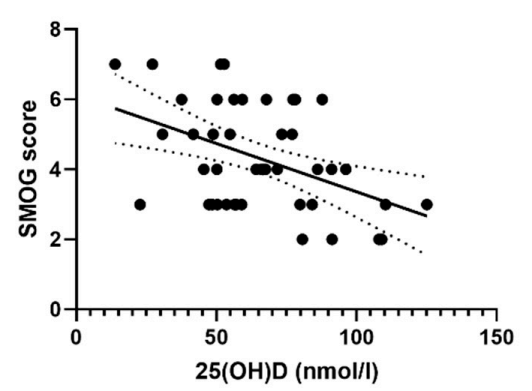

(c)

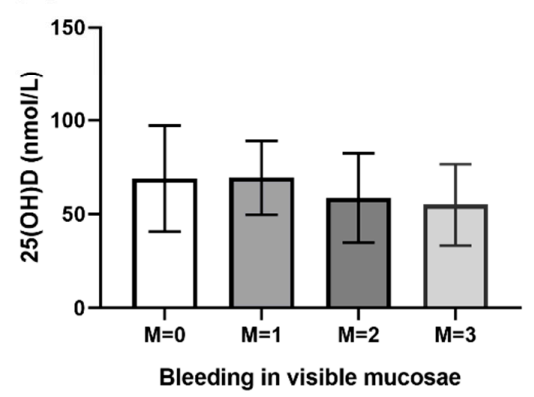

(b)

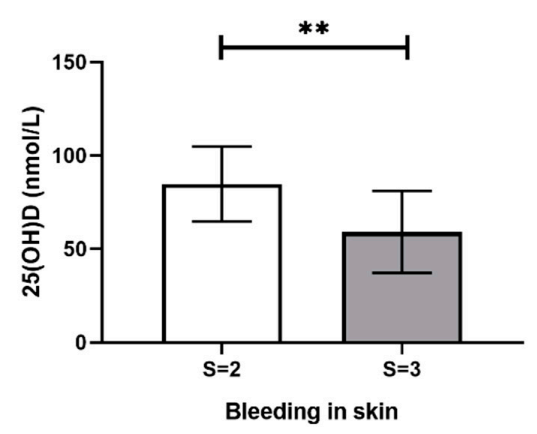

(d)

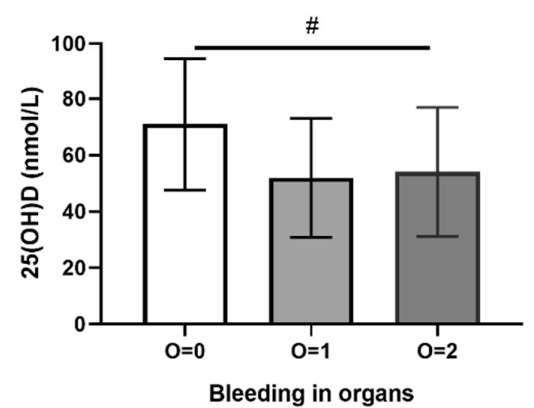

Figure 1. (a) Graph of linear regression between $25(\mathrm{OH}) \mathrm{D}$ value and skin-mucosa-organ-gradation (SMOG) bleeding score. The mean slope was -0.027 , with the intercept at 5.99 , while the $95 \%$ confidence interval (CI) was at -0.04 to -0.007 (intercept 4.6 to 7.3). $R^{2}=0.15, p=0.006$. (b) Difference between mean $25(\mathrm{OH}) \mathrm{D}$ values of two groups of patients with bleeding in skin (S) ratings 2 and 3 calculated with SMOG score ( $t$ test, $p=0.001,95 \%$ CI 10.5 to 40.5 ). (c) Distribution of mean 25(OH)D values in groups of patients with a different severity of bleeding in mucosae using the linear trend test. (d) Distribution of mean $25(\mathrm{OH}) \mathrm{D}$ values in groups of patients with a different severity of bleeding in organs (calculated with SMOG score) using the linear trend test (slope $-9.55,95 \%$ CI -0.54 to -18.56 , and $p=0.03$ ). $R^{2}$ coefficient of determination, ${ }^{* *} 0.001 \leq p<0.01$ for $t$ test, $\# 0.01<p<0.05$ for test for linear trend. S: Skin, M: Mucous membranes, O: Organs

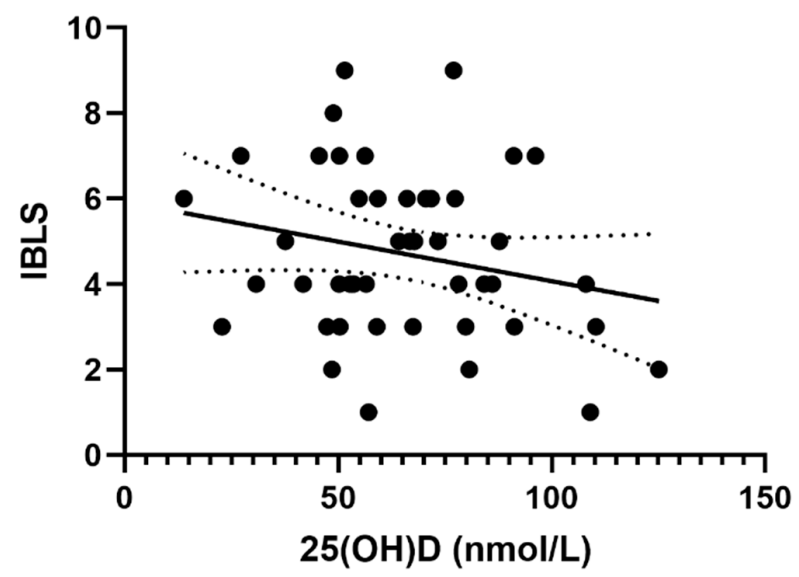

Figure 2. Graph of linear regression between Vitamin D (VD) value and ITP Bleeding Scale (IBLS) score. The mean slope was -0.018 , with the intercept at 5.92 , while the $95 \%$ CI was at -0.04 to -0.005 (intercept 4.2 to 7.6 ). $R^{2}=0.05, p=0.13$. 


\subsection{Correlation between $25(\mathrm{OH}) \mathrm{D}$ and Platelet Count}

There was no significant correlation between the $25(\mathrm{OH}) \mathrm{D}$ value and the platelet count at the time of diagnosis in the linear regression $\left(R^{2}=0.0001, p=0.93\right)$ or in the Spearman nonparametric correlation (Spearman $r=-0.06, p=0.67$ ).

\subsection{Correlation between Patient Gender and Age with 25(OH)D and SMOG Score}

As our secondary outcome, we evaluated the connection between patient gender and age with the severity of ITP and those same variables with hypovitaminosis D.

We found a positive correlation between patients' age and SMOG score (Spearman $r=0.33$, $p=0.02)$ i.e., older patients have higher SMOG score and therefore more severe bleeding. There was no difference in SMOG score between genders (similar median SMOG score for both genders, Mann Whitney test $p=0.15$ ).

We also found negative correlation between patients' age and 25(OH)D values (Pearson $r=-0.42$, $p=0.003)$, i.e., older patients have lower $25(\mathrm{OH}) \mathrm{D}$ values. There was no difference in $25(\mathrm{OH}) \mathrm{D}$ values between genders (the median $25(\mathrm{OH}) \mathrm{D}$ value for males was $70 \pm 25$, and for females $62 \pm 22, p=0.25$ ).

\section{Discussion}

There are some important findings in this study that will be subsequently discussed. First, patients with lower 25(OH)D values have more severe bleeding measured with the SMOG bleeding score at ITP diagnosis. This confirms our initial hypothesis that more severe hypovitaminosis $\mathrm{D}$ at the time of ITP diagnosis in children is associated with more severe bleeding. Secondly, the results showed that majority of patients with newly diagnosed ITP have hypovitaminosis D. However, we did not find a correlation between $25(\mathrm{OH}) \mathrm{D}$ values and platelet count at ITP diagnosis.

\subsection{Demographics and Clinical Presentation of ITP}

The patients analyzed in our study are similar and comparable with other patients in pediatric studies on ITP $[2,51,52]$. Severe bleeding was found in $28 \%$ of patients $(n=13)$ on the day of ITP diagnosis, which is slightly higher than the incidence reported in a large systematic review [13]. However, we had no patients with intracranial bleeding. That is the most severe complication of ITP and is relatively uncommon ( $0.4 \%$ of children) [13].

Until recently, the main marker for the severity of ITP was platelet count but it is concluded that clinical presentation, primarily bleeding events, was more significant in the assessment of ITP severity [6,14]. Therefore, ITP is considered severe only in patients who have clinically relevant bleeding and require additional therapeutic intervention or a change in the active treatment of ITP i.e., increased dose [6].

Recent studies also outline a problem in ITP bleeding severity quantification. Although two bleeding assessment tools that we used in our study (SMOG and IBLS) proved to be useful for the gradation of bleeding severity $[13,53,54]$, we still agree that a uniform high-quality bleeding assessment tool is needed for bleeding assessment in ITP.

\subsection{Correlation between Hypozitaminosis D and ITP}

The mean $25(\mathrm{OH}) \mathrm{D}$ value at ITP diagnosis in our study $(65 \pm 24 \mathrm{nmol} / \mathrm{L})$ can be considered as hypovitaminosis D $[47,48,55]$. Liu et al. reported a mean $25(\mathrm{OH}) \mathrm{D}$ value of $43 \pm 13 \mathrm{nmol} / \mathrm{L}$ in adult patients with ITP, while Yesil et al. reported a mean 25(OH)D value of $47 \pm 21 \mathrm{nmol} / \mathrm{L}$ in children with ITP [56,57]. The higher values in our study might be explained with the difference in the geographic origin of the patients that were included in our study. Our patients come from the coastal Croatia region, with a high incidence of sunny days [58], and therefore they may have higher 25(OH)D values. The study by Culic et al. had pediatric patients from a similar geographic region and also had lower 
$25(\mathrm{OH}) \mathrm{D}$ values, especially in the group of patients with chronic ITP $(35 \pm 20 \mathrm{nmol} / \mathrm{L})$ probably due to ITP treatment which additionally lowered their $25(\mathrm{OH}) \mathrm{D}$ values [49].

Similar to our study, a high incidence (up to $80 \%$ ) of hypovitaminosis D was previously reported in children with ITP [59]. Fattizzo et al., who evaluated adult patients with autoimmune cytopenias including ITP, suggested that VD influences the immune system by favorizing Th1 immune response and therefore lowers the chance for the development of autoimmune cytopenias including ITP [45].

To the best of our knowledge there are not many studies that connect ITP and hypovitaminosis D. But there are lots of studies connecting hypovitaminosis D with other autoimmune diseases, confirming the immunomodulatory influence of VD. The high incidence of hypovitaminosis D was found in patients with diabetes mellitus type 1 [60], autoimmune thyroid gland disease [61,62], multiple sclerosis [63], systemic lupus erythematosus [64,65], rheumatoid arthritis [66-68], and Crohn's disease [69]. A large well-designed study by Skaaby et al. [70] found significant inverse associations between vitamin $\mathrm{D}$ status and the development of autoimmune diseases. Bizzaro et al. [55] also confirmed that $25(\mathrm{OH}) \mathrm{D}$ values and VDR polymorphism are connected with various autoimmune diseases. As ITP is an autoimmune disease with a similar pathophysiological mechanism, we can assume there is a similar connection between VD and ITP.

Some authors even took a step forward and administered VD as a therapy in autoimmune diseases such as rheumatoid arthritis [71] and psoriatic arthritis [72] with promising results. With regard to ITP, Bockow and Kaplan described two cases of refractory ITP that were successfully treated with high-dose VD supplementation and hydroxychloroquine [73]. In several studies where VD supplementation therapy was implemented, the bottom limit of $25(\mathrm{OH}) \mathrm{D}$ value, at which the therapy started, was $50 \mathrm{nmol} / \mathrm{L}[60,61]$ and $75 \mathrm{nmol} / \mathrm{L}$ [73]. The British Society for Haematology recently also recommended VD supplementation in patients with ITP as a prevention for glucocorticoid-induced osteoporosis [74].

Based on our results, we can also recommend VD supplementation in patients with newly diagnosed ITP who have hypovitaminosis D.

\subsection{Correlation between VD and ITP Clinical Presentation}

In this study, we measured three indicators of the clinical severity of ITP at the time of the initial diagnosis: platelet count and two bleeding scores (IBLS and SMOG). Using linear regression and nonparametric correlation, we found a significant negative correlation between $25(\mathrm{OH}) \mathrm{D}$ value and SMOG score. We found a negative correlation between $25(\mathrm{OH}) \mathrm{D}$ value and IBLS score, but it was not significant. There was no significant correlation between $25(\mathrm{OH}) \mathrm{D}$ and platelet count as a third evaluated indicator of clinical severity. Some authors suggest that platelet count is not a quality marker of the clinical severity of ITP at all [6], and so that might partially explain this negative result.

To further investigate the correlation between SMOG score and $25(\mathrm{OH}) \mathrm{D}$, we evaluated each part of the SMOG score and found a significant negative correlation between $25(\mathrm{OH}) \mathrm{D}$ values and bleeding in the skin and the organ. In our opinion, the description of each type of bleeding in the SMOG system is more detailed, producing a more accurate final score, but it is time consuming and can be a problem in daily clinical practice.

To the best of our knowledge, there are no studies connecting 25(OH)D values and the clinical presentation of ITP in this manner. Fattizzo et al. found a correlation between VD levels and disease severity at the onset of ITP and other autoimmune cytopenias in adults [45], but they did not use bleeding assessment tools to assess the clinical presentation of ITP. Some authors that were mentioned before also found a connection between $25(\mathrm{OH}) \mathrm{D}$ values and the activity or severity of some autoimmune diseases $[64,67,69]$. Based on those results and the connection between VD and the incidence or activity of the autoimmune diseases, VD has been suggested as a possible therapy for them $[64,65,75]$. Antico et al. speculated that VD at high doses can affect the development or even the symptoms of the autoimmune diseases [40]. Accordingly, some of the authors suggested VD as a new therapy option for the treatment of ITP $[45,49,57]$. However, most of the mentioned authors agree that 
more studies, especially randomized clinical trials, are needed to further evaluate the influence of VD on autoimmune diseases.

\section{Limitations}

In this study, we only recruited patients from the coastal part of Croatia, and so there is a chance of selection bias based on the geographical origin of the patients. It is possible that patients who live in southern Croatia have higher sun exposure than in other geographic region [58] and therefore could have higher average $25(\mathrm{OH}) \mathrm{D}$ values than patients in other studies.

A second bias could be information bias. SMOG and IBLS bleeding scores are calculated from the clinical signs of bleeding. Pediatric hematologists described those signs during the clinical examination of the patient. Since the patient can be examined by a number of hematologists, there is a possibility of some form of information bias due to the subjective interpretation of the clinical finding. With standardization of the clinical examination of our patients and with good planning, we attempted to prevent this kind of bias.

\section{Conclusions}

Hypovitaminosis D is very common in children with ITP, as in other autoimmune diseases. Hypovitaminosis D influences the severity of ITP in children at the initial diagnosis of the disease and therapy with VD could be a new potential option for the treatment of ITP. To investigate the connection between $25(\mathrm{OH}) \mathrm{D}$ and the incidence and severity of ITP, further studies, especially randomized controlled studies, are needed.

Author Contributions: Conceptualization, D.P., J.M. and S.C.; Data curation, D.P. and M.B.; Investigation, D.P., M.B. and J.R.; Methodology, D.P., B.B. and J.M.; Resources, S.C. and J.R.; Software, B.B.; Supervision, J.M.; Visualization, B.B. and S.C.; Writing-original draft, D.P. and J.M.; Writing—review and editing, D.P. and J.M.

Funding: This research received no external funding.

Acknowledgments: We would like to thank the parents of the participants in this study for their consent to contribute to this study. We would also like to thank the nurses and pediatricians of the division for pediatric hematooncology at University Hospital of Split and Rijeka along with the staff of the laboratory department of the University Hospital of Split and Rijeka for their support in data collection.

Conflicts of Interest: The authors declare no conflict of interest.

\section{References}

1. Bussel, B.J. Immune Thrombocytopenia (ITP) in Children. Available online: http://www.uptodate.com/ (accessed on 20 October 2016).

2. Kühne, T.; Buchanan, G.R.; Zimmerman, S.; Michaels, L.A.; Kohan, R.; Berchtold, W.; Imbach, P.; Intercontinental Childhood ITP Study Group. A prospective comparative study of 2540 infants and children with newly diagnosed idiopathic thrombocytopenic purpura (ITP) from the Intercontinental Childhood ITP Study Group. J. Pediatr. 2003, 143, 605-608.

3. Kühne, T.; Berchtold, W.; Michaels, L.A.; Wu, R.; Donato, H.; Espina, B.; Tamary, H.; Rodeghiero, F.; Chitlur, M.; Rischewski, J.; et al. Newly diagnosed immune thrombocytopenia in children and adults: A comparative prospective observational registry of the Intercontinental Cooperative Immune Thrombocytopenia Study Group. Haematologica 2011, 96, 1831-1837. [CrossRef] [PubMed]

4. Labarque, V.; Van Geet, C. Clinical practice: Immune thrombocytopenia in paediatrics. Eur. J. Pediatr. 2014, 173, 163-172. [CrossRef] [PubMed]

5. Shaw, J.; Kilpatrick, K.; Eisen, M.; Tarantino, M. The incidence and clinical burden of immune thrombocytopenia in pediatric patients in the United States. Platelets 2019, 1-8. [CrossRef] [PubMed]

6. Rodeghiero, F.; Stasi, R.; Gernsheimer, T.; Michel, M.; Provan, D.; Arnold, D.M.; Bussel, J.B.; Cines, D.B.; Chong, B.H.; Cooper, N.; et al. Standardization of terminology, definitions and outcome criteria in immune thrombocytopenic purpura of adults and children: Report from an international working group. Blood 2009, 113, 2386-2393. [CrossRef] 
7. Donato, H.; Picón, A.; Martinez, M.; Rapetti, M.C.; Rosso, A.; Gomez, S.; Rossi, N.; Bacciedoni, V.; Schvartzman, G.; Riccheri, C.; et al. Demographic data, natural history, and prognostic factors of idiopathic thrombocytopenic purpura in children: A multicentered study from Argentina. Pediatr. Blood Cancer 2009, 52, 491-496. [CrossRef]

8. Imbach, P.; Kühne, T.; Müller, D.; Berchtold, W.; Zimmerman, S.; Elalfy, M.; Buchanan, G.R. Childhood ITP: 12 months follow-up data from the prospective registry I of the Intercontinental Childhood ITP Study Group (ICIS). Pediatr. Blood Cancer 2006, 46, 351-356. [CrossRef]

9. Blanchette, V.; Bolton-Maggs, P. Childhood immune thrombocytopenic purpura: Diagnosis and management. Hematol. Oncol. Clin. N. Am. 2010, 24, 249-273. [CrossRef]

10. Roganović, J. Idiopathic thrombocytopenic purpura in children. Acta Med. Acad. 2009, 38, 21-34.

11. Neunert, C.E.; Buchanan, G.R.; Imbach, P.; Bolton-Maggs, P.H.B.; Bennett, C.M.; Neufeld, E.J.; Vesely, S.K.; Adix, L.; Blanchette, V.S.; Kühne, T. Severe hemorrhage in children with newly diagnosed immune thrombocytopenic purpura. Blood 2008, 112, 4003-4008. [CrossRef]

12. Psaila, B.; Petrovic, A.; Page, L.K.; Menell, J.; Schonholz, M.; Bussel, J.B. Intracranial hemorrhage (ICH) in children with immune thrombocytopenia (ITP): Study of 40 cases. Blood 2009, 114, 4777-4783. [CrossRef] [PubMed]

13. Neunert, C.; Noroozi, N.; Norman, G.; Buchanan, G.R.; Goy, J.; Nazi, I.; Kelton, J.G.; Arnold, D.M. Severe bleeding events in adults and children with primary immune thrombocytopenia: A systematic review. J. Thromb Haemost 2015, 13, 457-464. [CrossRef] [PubMed]

14. British Committee for Standards in Haematology General Haematology Task Force. Guidelines for the investigation and management of idiopathic thrombocytopenic purpura in adults, children and in pregnancy. Br. J. Haematol. 2003, 120, 574-596. [CrossRef] [PubMed]

15. Bolton-Maggs, P.H.; Moon, I. Assessment of UK practice for management of acute childhood idiopathic thrombocytopenic purpura against published guidelines. Lancet 1997, 350, 620-623. [CrossRef]

16. Buchanan, G.R.; Adix, L. Grading of hemorrhage in children with idiopathic thrombocytopenic purpura. J. Pediatr. 2002, 141, 683-688. [CrossRef]

17. Page, L.K.; Psaila, B.; Provan, D.; Michael Hamilton, J.; Jenkins, J.M.; Elish, A.S.; Lesser, M.L.; Bussel, J.B. The immune thrombocytopenic purpura (ITP) bleeding score: Assessment of bleeding in patients with ITP. Br. J. Haematol 2007, 138, 245-248. [CrossRef]

18. Rodeghiero, F.; Michel, M.; Gernsheimer, T.; Ruggeri, M.; Blanchette, V.; Bussel, J.B.; Cines, D.B.; Cooper, N.; Godeau, B.; Greinacher, A.; et al. Standardization of bleeding assessment in immune thrombocytopenia: Report from the International Working Group. Blood 2013, 121, 2596-2606. [CrossRef]

19. Vesely, S.; Buchanan, G.R.; Cohen, A.; Raskob, G.; George, J. Self-reported diagnostic and management strategies in childhood idiopathic thrombocytopenic purpura: Results of a survey of practicing pediatric hematology/oncology specialists. J. Pediatr. Hematol. Oncol. 2000, 22, 55-61. [CrossRef]

20. Neunert, C.; Lim, W.; Crowther, M.; Cohen, A.; Solberg, L.; Crowther, M.A.; American Society of Hematology. The American Society of Hematology 2011 evidence-based practice guideline for immune thrombocytopenia. Blood 2011, 117, 4190-4207. [CrossRef]

21. Provan, D.; Stasi, R.; Newland, A.C.; Blanchette, V.S.; Bolton-Maggs, P.; Bussel, J.B.; Chong, B.H.; Cines, D.B.; Gernsheimer, T.B.; Godeau, B.; et al. International consensus report on the investigation and management of primary immune thrombocytopenia. Blood 2010, 115, 168-186. [CrossRef]

22. Rosthøj, S.; Hedlund-Treutiger, I.; Rajantie, J.; Zeller, B.; Jonsson, O.G.; Elinder, G.; Wesenberg, F.; Henter, J.I.; NOPHO ITP Working Group. Duration and morbidity of newly diagnosed idiopathic thrombocytopenic purpura in children: A prospective Nordic study of an unselected cohort. J. Pediatr. 2003, 143, 302-307.

23. Tarantino, M.D.; Young, G.; Bertolone, S.J.; Kalinyak, K.A.; Shafer, F.E.; Kulkarni, R.; Weber, L.C.; Davis, M.L.; Lynn, H.; Nugent, D.J.; et al. Single dose of anti-D immune globulin at $75 \mathrm{microg} / \mathrm{kg}$ is as effective as intravenous immune globulin at rapidly raising the platelet count in newly diagnosed immune thrombocytopenic purpura in children. J. Pediatr. 2006, 148, 489-494. [CrossRef] [PubMed]

24. Blanchette, V.S.; Luke, B.; Andrew, M.; Sommerville-Nielsen, S.; Barnard, D.; de Veber, B.; Gent, M. A prospective, randomized trial of high-dose intravenous immune globulin $\mathrm{G}$ therapy, oral prednisone therapy, and no therapy in childhood acute immune thrombocytopenic purpura. J. Pediatr. 1993, 123, 989-995. [CrossRef] 
25. Treutiger, I.; Rajantie, J.; Zeller, B.; Henter, J.I.; Elinder, G.; Rosthøj, S.; Group, N.I.S. Does treatment of newly diagnosed idiopathic thrombocytopenic purpura reduce morbidity? Arch. Dis. Child. 2007, 92, $704-707$. [CrossRef]

26. Blanchette, V.; Imbach, P.; Andrew, M.; Adams, M.; McMillan, J.; Wang, E.; Milner, R.; Ali, K.; Barnard, D.; Bernstein, M. Randomised trial of intravenous immunoglobulin $\mathrm{G}$, intravenous anti-D, and oral prednisone in childhood acute immune thrombocytopenic purpura. Lancet 1994, 344, 703-707. [CrossRef]

27. Grainger, J.D.; Locatelli, F.; Chotsampancharoen, T.; Donyush, E.; Pongtanakul, B.; Komvilaisak, P.; Sosothikul, D.; Drelichman, G.; Sirachainan, N.; Holzhauer, S.; et al. Eltrombopag for children with chronic immune thrombocytopenia (PETIT2): A randomised, multicentre, placebo-controlled trial. Lancet 2015, 386, 1649-1658. [CrossRef]

28. DeLuca, H.F. Overview of general physiologic features and functions of vitamin D. Am. J. Clin. Nutr. 2004, 80, 1689S-1696S. [CrossRef]

29. Yee, Y.K.; Chintalacharuvu, S.R.; Lu, J.; Nagpal, S. Vitamin D receptor modulators for inflammation and cancer. Mini Rev. Med. Chem. 2005, 5, 761-778. [CrossRef]

30. Fernandes de Abreu, D.A.; Eyles, D.; Féron, F. Vitamin D, a neuro-immunomodulator: Implications for neurodegenerative and autoimmune diseases. Psychoneuroendocrinology 2009, 34, S265-S277. [CrossRef]

31. Bikle, D. Nonclassic actions of vitamin D. J. Clin. Endocrinol. Metab. 2009, 94, 26-34. [CrossRef]

32. Jørgensen, S.P.; Bartels, L.E.; Agnholt, J.; Glerup, H.; Nielsen, S.L.; Hvas, C.L.; Dahlerup, J.F. Vitamin D insufficiency-Possible etiologic factor of autoimmune diseases. Ugeskr. Laeger 2007, 169, 3655-3660. [PubMed]

33. Dusso, A.S.; Brown, A.J.; Slatopolsky, E. Vitamin D. Am. J. Physiol. Renal Physiol. 2005, 289, F8-F28. [CrossRef] [PubMed]

34. Cantorna, M.T.; Zhu, Y.; Froicu, M.; Wittke, A. Vitamin D status, 1,25-dihydroxyvitamin D3, and the immune system. Am. J. Clin. Nutr. 2004, 80, 1717S-1720S. [CrossRef] [PubMed]

35. Borges, M.C.; Martini, L.A.; Rogero, M.M. Current perspectives on vitamin D, immune system, and chronic diseases. Nutrition 2011, 27, 399-404. [CrossRef]

36. Cippitelli, M.; Santoni, A. Vitamin $\mathrm{D}_{3}$ : A transcriptional modulator of the interferon-gamma gene. Eur. J. Immunol. 1998, 28, 3017-3030. [CrossRef]

37. Prentice, A.; Goldberg, G.R.; Schoenmakers, I. Vitamin D across the lifecycle: Physiology and biomarkers. Am. J. Clin. Nutr. 2008, 88, 500S-506S. [CrossRef]

38. Aranow, C. Vitamin D and the immune system. J. Investig. Med. 2011, 59, 881-886. [CrossRef]

39. Pludowski, P.; Holick, M.F.; Pilz, S.; Wagner, C.L.; Hollis, B.W.; Grant, W.B.; Shoenfeld, Y.; Lerchbaum, E.; Llewellyn, D.J.; Kienreich, K.; et al. Vitamin D effects on musculoskeletal health, immunity, autoimmunity, cardiovascular disease, cancer, fertility, pregnancy, dementia and mortality-A review of recent evidence. Autoimmun. Rev. 2013, 12, 976-989. [CrossRef]

40. Antico, A.; Tampoia, M.; Tozzoli, R.; Bizzaro, N. Can supplementation with vitamin D reduce the risk or modify the course of autoimmune diseases? A systematic review of the literature. Autoimmun. Rev. 2012, 12, 127-136. [CrossRef]

41. Deluca, H.F.; Cantorna, M.T. Vitamin D: Its role and uses in immunology. FASEB J. 2001, 15, $2579-2585$. [CrossRef]

42. Adorini, L. Immunomodulatory effects of vitamin D receptor ligands in autoimmune diseases. Int. Immunopharmacol. 2002, 2, 1017-1028. [CrossRef]

43. Arnson, Y.; Amital, H.; Shoenfeld, Y. Vitamin D and autoimmunity: New aetiological and therapeutic considerations. Ann. Rheum. Dis. 2007, 66, 1137-1142. [CrossRef] [PubMed]

44. Zold, E.; Barta, Z.; Bodolay, E. Vitamin D deficiency and connective tissue disease. Vitam. Horm. 2011, 86, 261-286. [CrossRef] [PubMed]

45. Fattizzo, B.; Zaninoni, A.; Giannotta, J.A.; Binda, F.; Cortelezzi, A.; Barcellini, W. Reduced 25-OH vitamin D in patients with autoimmune cytopenias, clinical correlations and literature review. Autoimmun. Rev. 2016, 15, 770-775. [CrossRef]

46. Von Elm, E.; Altman, D.G.; Egger, M.; Pocock, S.J.; Gotzsche, P.C.; Vandenbroucke, J.P. The Strengthening the Reporting of Observational Studies in Epidemiology (STROBE) Statement: Guidelines for reporting observational studies. Int. J. Surg. 2014, 12, 1495-1499. [CrossRef] 
47. Holick, M.F. Vitamin D status: Measurement, interpretation, and clinical application. Ann. Epidemiol. 2009, 19,73-78. [CrossRef]

48. Saggese, G.; Vierucci, F.; Prodam, F.; Cardinale, F.; Cetin, I.; Chiappini, E.; De' Angelis, G.L.; Massari, M.; Miraglia Del Giudice, E.; Miraglia Del Giudice, M.; et al. Vitamin D in pediatric age: Consensus of the Italian Pediatric Society and the Italian Society of Preventive and Social Pediatrics, jointly with the Italian Federation of Pediatricians. Ital. J. Pediatr. 2018, 44, 51. [CrossRef]

49. Čulić, S.; Markić, J.; Petrović, D.; Konjevoda, P.; Pavelić, J. Serum vitamin D levels in children with newly diagnosed and chronic immune thrombocytopenia. Semin. Hematol. 2016, 53 (Suppl. 1), S67-S69. [CrossRef]

50. Quinn, G.P.; Keough, M.J. Experimental Design and Data Analysis for Biologist. Available online: http://www.lacbiosafety.org/wp-content/uploads/2011/09/experimental-design-and-data-analysisfor-biologists1.pdf (accessed on 20 July 2017).

51. Alam, M.M. Idiopathic thrombocytopenic purpura in children: A 10 years experience at tertiary care hospital. J. Pak. Med. Assoc. 2014, 64, 1358-1362.

52. Paling, A.; Stefan, D.C. Idiopathic thrombocytopenic purpura in childhood: A 10-year audit. Hematology 2008, 13, 175-180. [CrossRef]

53. Kumar, M.; Dutta, S.; Bhattyacharyya, M. Application of ITP-BAT bleeding score in clinical practice. Int. J. Hematol. 2015, 101, 207-208. [CrossRef] [PubMed]

54. Arnold, D.M. Platelet count or bleeding as the outcome in ITP trials? Am. J. Hematol. 2012, 87, $945-946$. [CrossRef] [PubMed]

55. Bizzaro, G.; Antico, A.; Fortunato, A.; Bizzaro, N. Vitamin D and Autoimmune Diseases: Is Vitamin D Receptor (VDR) Polymorphism the Culprit? Isr. Med. Assoc. J. 2017, 19, 438-443. [PubMed]

56. Yesil, S.; Tanyildiz, H.G.; Tekgunduz, S.A.; Toprak, S.; Fettah, A.; Dikmen, A.U.; Sahin, G. Vitamin D receptor polymorphisms in immune thrombocytopenic purpura. Pediatr. Int. 2017, 59, 682-685. [CrossRef] [PubMed]

57. Liu, W.; Li, H.; Hao, Y.; Li, Y.; Lv, M.; Xue, F.; Liu, X.; Zhang, L.; Yang, R. Decreased immunosuppressive actions of $1 \alpha, 25$-dihydroxyvitamin D3 in patients with immune thrombocytopenia. Mol. Immunol. 2016, 78, 89-97. [CrossRef] [PubMed]

58. Smek, L. Climate Atlas of Croatia; Zaninovic, K., Ed.; Meterological and Hydrological Service of Croatia: Zagreb, Croatia, 2008; pp. 83-85.

59. Lassandro, G.; Carriero, F.; Palmieri, V.; Palladino, V.; Amoruso, A.; Gallone, M.F.; Del Vecchio, G.C.; Tafuri, S.; Russo, G.; Giordano, P. Serum D vitamin levels in children with immune thrombocytopenia. Endocr. Metab. Immune Disord. Drug Targets 2019, 31203812. [CrossRef]

60. Hafez, M.; Hassan, M.; Musa, N.; Abdel Atty, S.; Azim, S.A. Vitamin D status in Egyptian children with type 1 diabetes and the role of vitamin D replacement in glycemic control. J. Pediatr. Endocrinol. Metab. 2017, 30, 389-394. [CrossRef]

61. Simsek, Y.; Cakır, I.; Yetmis, M.; Dizdar, O.S.; Baspinar, O.; Gokay, F. Effects of Vitamin D treatment on thyroid autoimmunity. J. Res. Med. Sci. 2016, 21, 85. [CrossRef]

62. Wang, J.; Lv, S.; Chen, G.; Gao, C.; He, J.; Zhong, H.; Xu, Y. Meta-analysis of the association between vitamin $\mathrm{D}$ and autoimmune thyroid disease. Nutrients 2015, 7, 2485-2498. [CrossRef]

63. Lu, C.Z.; Jensen, M.A.; Arnason, B.G. Interferon gamma- and interleukin-4-secreting cells in multiple sclerosis. J. Neuroimmunol. 1993, 46, 123-128. [CrossRef]

64. Amital, H.; Szekanecz, Z.; Szucs, G.; Danko, K.; Nagy, E.; Csepany, T.; Kiss, E.; Rovensky, J.; Tuchynova, A.; Kozakova, D.; et al. Serum concentrations of $25-\mathrm{OH}$ vitamin D in patients with systemic lupus erythematosus (SLE) are inversely related to disease activity: Is it time to routinely supplement patients with SLE with vitamin D? Ann. Rheum. Dis. 2010, 69, 1155-1157. [CrossRef] [PubMed]

65. Wright, T.B.; Shults, J.; Leonard, M.B.; Zemel, B.S.; Burnham, J.M. Hypovitaminosis D is associated with greater body mass index and disease activity in pediatric systemic lupus erythematosus. J. Pediatr. 2009, 155, 260-265. [CrossRef] [PubMed]

66. Song, G.G.; Bae, S.C.; Lee, Y.H. Association between vitamin D intake and the risk of rheumatoid arthritis: A meta-analysis. Clin. Rheumatol. 2012, 31, 1733-1739. [CrossRef] [PubMed]

67. Lin, J.; Liu, J.; Davies, M.L.; Chen, W. Serum Vitamin D Level and Rheumatoid Arthritis Disease Activity: Review and Meta-Analysis. PLoS ONE 2016, 11, e0146351. [CrossRef] [PubMed] 
68. Kerr, G.S.; Sabahi, I.; Richards, J.S.; Caplan, L.; Cannon, G.W.; Reimold, A.; Thiele, G.M.; Johnson, D.; Mikuls, T.R. Prevalence of vitamin D insufficiency/deficiency in rheumatoid arthritis and associations with disease severity and activity. J. Rheumatol. 2011, 38, 53-59. [CrossRef]

69. Sadeghian, M.; Saneei, P.; Siassi, F.; Esmaillzadeh, A. Vitamin D status in relation to Crohn's disease: Meta-analysis of observational studies. Nutrition 2016, 32, 505-514. [CrossRef]

70. Skaaby, T.; Husemoen, L.L.; Thuesen, B.H.; Linneberg, A. Prospective population-based study of the association between vitamin D status and incidence of autoimmune disease. Endocrine 2015, 50, 231-238. [CrossRef]

71. Andjelkovic, Z.; Vojinovic, J.; Pejnovic, N.; Popovic, M.; Dujic, A.; Mitrovic, D.; Pavlica, L.; Stefanovic, D. Disease modifying and immunomodulatory effects of high dose 1 alpha $(\mathrm{OH}) \mathrm{D} 3$ in rheumatoid arthritis patients. Clin. Exp. Rheumatol. 1999, 17, 453-456.

72. Huckins, D.; Felson, D.T.; Holick, M. Treatment of psoriatic arthritis with oral 1,25-dihydroxyvitamin D3: A pilot study. Arthritis Rheum. J. Am. Coll. Rheumatol. 1990, 33, 1723-1727. [CrossRef]

73. Bockow, B.; Kaplan, T.B. Refractory immune thrombocytopenia successfully treated with high-dose vitamin D supplementation and hydroxychloroquine: Two case reports. J. Med. Case Rep. 2013, 7, 91. [CrossRef]

74. Hill, Q.A.; Grainger, J.D.; Thachil, J.; Provan, D.; Evans, G.; Garg, M.; Bradbury, C.; Bagot, C.; Kanis, J.A.; Compston, J.E. The prevention of glucocorticoid-induced osteoporosis in patients with immune thrombocytopenia receiving steroids: A British Society for Haematology Good Practice Paper. Br. J. Haematol. 2019, 185, 410-417. [CrossRef] [PubMed]

75. Wang, Y.; Zhang, F.; Wang, S.; Shang, X.; Luo, S.; Zhou, H.; Shi, H.; Cai, L. Serum Vitamin D Level is Inversely Associated With Anti-Cyclic Citrullinated Peptide Antibody Level and Disease Activity in Rheumatoid Arthritis Patients. Arch. Rheumatol. 2016, 31, 64-70. [CrossRef] [PubMed]

(C) 2019 by the authors. Licensee MDPI, Basel, Switzerland. This article is an open access article distributed under the terms and conditions of the Creative Commons Attribution (CC BY) license (http://creativecommons.org/licenses/by/4.0/). 